\title{
Cognitive-behavioral Therapy: a theoretical review of its bases
}

\author{
Terapia cognitivo-conductual: una revisión teórica de sus bases
}

\author{
Julio A. Hernández-Pineda ${ }^{a}$, Edén A. Medina-Guerrero ${ }^{b} \&$ José A. Castillo-Martínez $^{c}$
}

\begin{abstract}
:
This article is a theoretical review essay, which aims to present the events that are considered most relevant in the development and consolidation of Cognitive-Behavioral Therapy (CBT) and which in turn have positioned it as a therapy of choice for Different psychological problems. A review was carried out with two of the most accessible digital search engines for undergraduate students, using search keywords according to the objective of this article. Identifying that cognitive-behavioral therapy is understood as the application of scientific psychology to clinical practice in a systematic and structured way. This model based on behaviour modification because of its solid theoretical and experimental basis, which emphasizes the empirical verification of the techniques during its application. What makes CBT an effective, efficient, and timely clinical practice, improving the quality of life of users and positioning themselves in front of other psychological models in terms of efficacy.
\end{abstract}

Keywords:

Behavior modification, Psychotherapy, Evidence-based psychology, Effectiveness, Efficacy

\section{Resumen:}

Este artículo es un ensayo de revisión teórica, cuyo objetivo es presentar los eventos que se consideran más relevantes en el desarrollo y la consolidación de la terapia cognitiva conductual (TCC) y que a su vez la han posicionado como una terapia de elección para diferentes problemas psicológicos. Se realizó una revision con dos de los motores de búsqueda digital más accesibles para estudiantes universitarios, utilizando palabras clave de búsqueda de acuerdo con el objetivo de este artículo. Identificar que la terapia cognitivo-conductual se entiende como la aplicación de la psicología científica a la práctica clínica de manera sistemática y estructurada. Este modelo se basa en la modificación del comportamiento debido a su sólida base teórica y experimental, que enfatiza la verificación empírica de las técnicas durante su aplicación. Lo que hace que la TCC sea una práctica clínica efectiva, eficiente y oportuna, que mejora la calidad de vida de los usuarios y se posiciona frente a otros modelos psicológicos en términos de eficacia.

Palabras Clave:

Modificación de conducta, Psicoterapia, Psicología basada en evidencia, Efectividad, Eficacia

\section{INTRODUCTION}

Cognitive-behavioral therapy (CBT) is a model of psychological intervention, structured and grounded on scientific and empirical bases that have set the pattern for the praxis of clinical, educational, and organizational psychologists, among others. It is within the treatments of choice and the most used therapies today, not only for its development and proliferation but for its effectiveness and efficiency, which places it within the short and therefore economically accessible therapies (Hernández, 2017). Also, in a short time is achieved the objective that has been established at the beginning of the treatment.

Ruiz, Díaz, and Villalobos (2013) define CBT as the systematic application of psychological science in the clinical context. These procedures were derived from the learning principles and theories, which are well-grounded by empirical evidence and basic research, what they had called the first generation of cognitive-behavioral therapies: Behavior Therapy (CT)

This therapeutic approach has become the psychotherapeutic approach with more significant evidence for a large number of psychological problems. The term psychological problem is used (Pérez \& Fernández, 2008) because it is understood as something that is within reach of the user to be able to solve, such as the daily circumstances of life, and not only as a pathogen that is causing a particular behavior.

Nowadays, other authors affirm that:

Under the heading of cognitive-behavioral, a set of schools, theories, and techniques are defined. They give way to a therapeutic system based on a theory of psychopathology and a body of techniques derived from Experimental Psychology, Social Learning, Cognitive Sciences, Information Processing, and Systems theory (Hernández \& Sánchez, 2007, p. 9).CBT

\footnotetext{
a Autor de correspondencia, Universidad Autónoma de Guerreo, Instituto de Terapias Cognitivo Conductuales, https://orcid.org/0000-00029871-7258, Email: janherpivr@ gmail.com

b Universidad Autónoma del Estado de Hidalgo, Instituto de Ciencias de la Salud, https://orcid.org/0000-0003-0162-4483, Email: psic.eden@gmail.com

c Universidad Autónoma de Guerreo, Instituto de Terapias Cognitivo Conductuales, https://orcid.org/0000-0002-0943-9074, Email: psicoengel@gmail.com
} 
groups a wide range of intervention techniques and procedures specific to each disorder or problem that can be cognitive, behavioral, and emotional, in which the person may be presenting difficulties, and they affected their performance in some vital areas. Also, to develop in people some skills to had better social adaptation and increase their quality of liferelated to their satisfaction and perception.

\section{METHOD}

This text is a theoretical revision essay. In this review, digital search engines were used to analyze journal articles with scientific content and publications of empirical research in the field of Psychology. In a second stage, books, manuals, and protocols of cognitive-behavioral therapy were also reviewed in which precise descriptions are made of the scientific and empirical foundations and bases that support the effectiveness of the techniques used within this model to solve the problems of psychological nature. The search was conducted considering the essential databases to which undergraduate students have easy access as the first resource in the search for articles on this topic (Dialnet and Google Scholar). Logical operators and search keywords were used, such as: "bases of CBT, fundamentals of CBT, scientific bases of CBT, fundamentals of Cognitive Behavioral Therapy." Once the articles were collected, the most appropriate ones were reviewed to integrate the information as a theoretical essay review.

\section{RESULTS}

\section{Basis and foundations of CBT}

Under the title CBT, different interventions are grouped that can be organized according to their level of response and objectives, varying from behavioral, cognitive, and currently contextual ones.

\section{Basic and Behavioral Research}

Its genesis, development, and consolidation is related mainly to Behavior Therapy (BT) or Behavior Modification (BM). Since its beginnings in the $50 \mathrm{~s}$, as an alternative intervention to psychoanalysis, it was born with a solid theoretical basis and experimental foundation due to its interest in basic research (Froján \& Calero, 2011). Considered a powerful technology (Bornas \& Noguera, 2002) and the strongest pillar on which cognitive-behavioral therapies are supported.

From the investigations of the Russian physiologist Pavlov who, in the early twentieth century, showed that a neutral stimulus (sound of a bell), which caused no response in the organism and has no formal properties in common with another stimulus, he called unconditional stimulus (food). For its part, food does cause natural reactions in the body. By presenting them almost simultaneously, the neutral stimulus begins to elicit responses of the organism similar to those caused by the unconditional or unconditioned (in this case, salivation). Once the stimulus (before neutral) acquires the ability to elicit the salivation response, it changes its name to a conditioned stimulus, and the response, in the same way, changes to a conditioned response in a procedure called responsive, classical or Pavlovian conditioning. The discovery of classical conditioning allowed us to understand how an unconditioned response (e.g., fear or anxiety) could be evoked in the face of stimuli or situations that previously seemed harmless and give clear explanations of how a problem can be acquired as a specific Phobia.

In America, the one considers as primarily responsible for psychology focusing on behavior is John B. Watson, who, with his student Rayner and using the procedures of classical conditioning, managed to induce an experimental phobia. He also encouraged one of his disciples, Mary Cover Jones, to follow his line of research and a few years later he was able to treat a phobia (Pérez, Gutiérrez, García, \& Gómez, 2010).

This event, it could be said that, starts the BT, inspiring other researchers to transfer the experimental findings to the clinical field of psychology. Another of the most important contributions is Skinner's operant conditioning, in which it is postulated that the behavior will be more likely to occur or not due to the consequences that it has. Positive reinforcement, negative reinforcement, positive punishment, negative punishment, and extinction are some of the fundamental premises (principles) that were derived from the Behavioral Experimental Analysis (see Holland \& Skinner, 1990, for the revision of these concepts). If we systematically applied these principles, we can modify "maladaptive" and "adapted" behaviors that are acquired under the same learning principles. In this sense, in the field of Behavioral Modification, instead of referring to normal or abnormal pathological or healthy behaviors, it is preferred to use the terms of excesses or deficits.

The investigations named early and others such as Wolpe (1958) with systematic desensitization, Meichenbaum (1974) with training in self-instruction, Mahoney (1974) with the mediation model, among others, have made possible the evolution and consolidation of CBT as therapy of choice for different psychological problems.

\section{About empirical evidence}

A relevant period for BT began in 1970, including cognitive and social aspects. The cognitive variable was included because the Stimulus-Response (E-R) model was insufficient to give a complete explanation of human behavior. That was an advance for this psychological therapy proposal because it showed that it did not neglect the relevant aspects of psychological science (emotion, cognition, memory, etc.). During this critical period (70's), one of the most representative theories was the Social Learning Theory that weighted the social influence and the ability of a persona to self-regulate his behavior. The works of Bandura and the appearance of the relevance of cognitive aspects in the BT gave way to the so-called cognitive revolution, where the highest value was attributed to thoughts and mental structures. The incorporation of cognitive variables changed the conceptualization and treatments of psychological problems and their implications in clinical practice (Ruiz, Díaz \& Villalobos, 2013). A crucial moment was the publication of the work Cognition and behavior modification by Mahoney (1974). By the early '80s, CBT was already well positioned as an effective and efficient therapy that could be compared, in terms of efficacy, with pharmacological treatments.

\section{Clinical application}


The interest of treatment is the modification of maladaptive responses without neglecting internal or private processes (emotion, cognition, physiology, etc.). Behavior is understood as a learning process as a result of the events that have happened in the subject's environment without forgetting biological and cultural aspects. Although there are many misunderstandings, mostly by people unfamiliar with the theoretical foundations of the model, CBT not only focuses on behavior or thoughts but also takes into account other variables as emotion, physiology, and environment (Dattilio \& Padesky, 1995). These five variables usually complemented by the subject's clinical history and the functional analysis of the behavior that is important to understand the problem and focusing on the present. Consequently, the goal of the treatment is cognitive, emotional, and behavioral change, which can be achieved by reducing the user's maladaptive behavior.

CBT weighs the evaluation of the effectiveness of interventions in treatments, which originates in an empirical approach. A useful intervention can be qualified with all changes that indicate improvements in the target behavior.

The Cognitive Behavioral Therapist is essentially an active manager in what refers to psychotherapy, actively involving the patient in his treatment. First showing him how he operates to modify the variables within the office and then asking for specific tasks such as thought detection, questioning techniques and behavioral experiments that serve to verify the truthfulness or functionality of their assumptions that give meaning to their experiences (Bunge, Gomar, \& Mandil, 2011). As the treatment progresses, the patient becomes the specialist and can benefit from what he learned in sessions. This way of working together with the patient (forming a collaborative team), Beck, Rush, Shaw, and Emery (1983) called it collaborative empiricism.

The patient has active participation because people tend to make errors in the processing of information (cognitive distortions) that they receive from outside, distorted by thought patterns that refer to a negative view of the world, themselves, and the future (cognitive triad). Perpetuating the schemes, which are cognitive structures that will determine the aspects that will be taken care of, resulting in psychological distress. That is why the active participation of the patient in what he considers a problem is necessary because they are the only ones who can access the world inaccessible to the therapist. In 1955, Ellis proposed Rational Emotive Behavioral Therapy (REBT) (Ellis \& Dryden, 1989).

Ellis, in the REBT, proposes his ABC model of emotion, which is a graphic representation of a constellation of variables that make up the psychological event. ABC model allows conceptualizing the psychological problems of psychotherapy users in a simple way. Where A represents the adversity or situation from which the inferences are derived. And these are what activate the belief system B, which attributed the emotional, physiological, and behavioral consequences $\mathrm{C}$, which are the perceived problems for the patient. These proposals for intervention are based on the already well-known stoic premise that it is not the events that disturb or alter man, but the interpretation he makes of the facts (Epictetus, 1st century AD, cited in Lega, Horse \& Ellis, 1997). Which is also considered a cornerstone in CBT.

\section{Techniques and strategies applied}

Some of the best-known techniques that were derived from the theoretical knowledge achieved by this model are cognitive restructuring techniques. Which focuses on the identification of thoughts that are considered problematic and then correct or replace them with more adaptive ones that allow the achievement of the objectives. These techniques are very representative of Rational Emotive Behavioral Therapy (REBT) and Beck's Cognitive Therapy (CT).

Other techniques have stood out for their effectiveness, their easy implementation and the possibility of providing the user with practical knowledge to improve their cognitions, emotions and behaviors (See Figure 1).

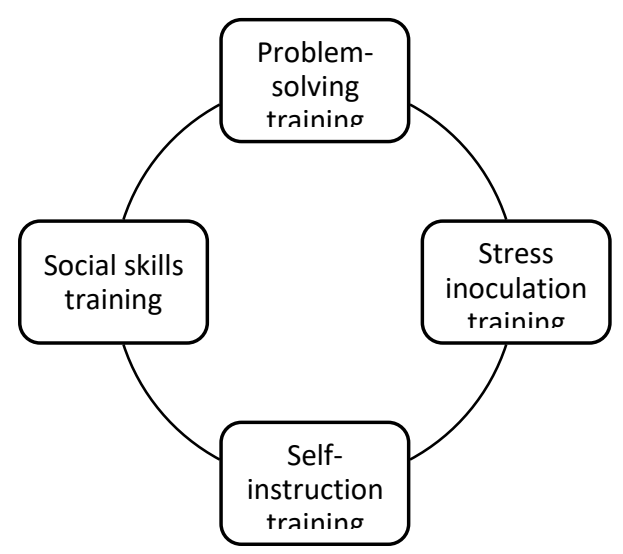

Figure 1. Some of the best-known intervention strategies of the cognitive-behavioral model

These strategies focus on the relationship between what is thought (cognition), is felt (emotion/affection), and is done (behavior)

Starting from the fact that CBT assumes that emotions and behaviors are mostly a product of what we think (Kendall, 1991, cited in Stallard, 2007). Therefore, cognitive-behavioral techniques are intended to help users of psychotherapy to change the problematic patterns of behavior, facilitating that they change the content of their thoughts for a more rational explanation of the events they live.

\section{Some distinctive features and their contributions to mental health}

What characterizes CBT is that it is based on a collaborative team between the therapist and the client. From the first sessions in the psychoeducation part, the therapist socializes the possible genesis, development, and maintenance of the problem, which increases the knowledge of themselves and the variables related to their problem. This activity involves the client in his treatment, promoting in him the development of new skills that will help him to the solution of future vicissitudes that are presented and promoting independence to develop new skills that facilitate the achievement of his objectives. It is a model of brief therapy (in general with limited time, between 15 or 20 sessions) with clear goals, operating in a structured way. 
The cognitive-behavioral therapist knows what he will do in each meeting because the sessions have a structure that consists of at least six components (See Figure 2) acording to Friedberg and McClure (2005). These components somehow guarantee to work for objectives within the session without forgetting that the therapist has the freedom to change it into the present contingencies of the session.

1) Assess the mood

Figure 2. The General structure of a session in the cognitivebehavioral model

Cognitive-behavioral therapy also offers precise explanations of the psychological problem that occupy the place of diagnosis. The case formulation and treatment plan (Nezu, Nezu \& Lombardo, 2006) would be the option to follow to understand the current problem of the psychotherapy user. This formulation is a graphic representation for the therapist that allows him to see the predisposing events as well as the precipitants (distant variables and background) of the client's complaints, which will enable the therapist to design a treatment program following the specific problem of the client.

A large number of clinicians and researchers use evidencebased therapies, which have given relief to a large number of problems, thus contributing to the benefit of the society's mental health from children to older adults in very diverse circumstances and different backgrounds.

Currently, cognitive-behavioral therapies are probably the most used due to a large amount of evidence they have in their interventions, to the degree that CBT and Evidence-Based Psychotherapy (PBE) has come to be understood as synonyms (Pérez, 2019). They have reports of interventions for complex problems such as trichotillomania (Morales, 2012), smoking (Froján \& Becoña, 1999), communication disorders, learning (Caballo \& Simón, 2002), to name a few. There are also complete intervention manuals for anxiety, sexual dysfunctions, dissociative, somatoform, impulse control, mood disorders, bipolar, schizophrenia, sleep disturbances, and partner problems (Barlow, 2018; Caballo, 1997). All this evidence is contributing effectively and efficiently to the mental health of a large number of people who benefit from these empirical treatments.
The techniques that makeup CBT are based on the scientific principles of learning psychology, classical conditioning, operant conditioning, social learning theory, and cognitive learning.

Other techniques also had their basis in clinical experience to what we have referred to as evidence-based therapies. This body of knowledge, called Cognitive-behavioral Therapy, has a history of birth, development, strengthening, and is consolidated. This model tries to intervene promptly in the discomfort of the subject showing deep respect for the emotional pain of people suffering from a disorder (Galasso, 2011). In this way, and with the evidence of the experiments and investigations, instead of investigating the possible underlying conflicts or problems, behavioral therapists began to focus on the manipulation of variables that were objective. They set aside the subjective definitions to focus objectively on the behavior.

CBT has demonstrated its effectiveness in a large number of psychological disorders and problems in the daily life of the human being. Based on the behavior modification, because it strictly adhered to the scientific method, establishing laws that explain the interaction of an organism, alive, with the variables of the environment.

The era of technology and the birth of artificial systems also supported these (cognitive) theories, serving as an analogy in the processing of information in thinking subjects.

CBT is characterized by putting at the service of the client the scientific principles of psychology for personal growth and development.

Arguing that behaviors are learned (both adaptive and maladaptive) under the same conditions and based on this, the learning process can be reversed or new behaviors; more adaptive or functional responses can be learned, according to the context. Dissatisfaction with the behavioral paradigm and its inability to explain the complexity of human behaviors gave way to the integration of the cognitive variable and, with it, the birth of CBT to provide a more structured and detailed explanation of the variables that affect behavior. By the '80s, CBT already circumscribed a great variety of these types of techniques, which were positioned for their effectiveness in clinical interventions.

For CBT to maintain its scientific status, it should continue doing empirical studies with experimental and control groups, comparative studies, meta-analysis, maintain methodological skepticism, be self-critical, that is, that CBT is fallible and perfectible.

What psychologists need now is to focus on why it works, highlighting the role of language and context as relevant tools in psychotherapy. To be aware of the process of cognitivebehavioral interventions would allow us for more precise and reliable indicators of the expected change in a psychotherapeutic intervention.

\section{REFERENCES}


Barlow, D. H. (2018). Manual clínico de tratamientos psicológicos: tratamiento paso a paso. México: Manual Moderno.

Beck, A. T., Rush, A. J., Shaw, B. F. \& Emery G. (1983/2010). Terapia cognitiva de la depresión (19 ${ }^{a}$ ed.). Bilbao: Desclée de Brouwer.

Bornas, X., \& Noguera, M. (2002). Bases científicas de la terapia de conducta: nuevas propuestas para un viejo problema. International Journal of Clinical and Health Psychology, 2(1), pp. 9-24.

Bunge, E. Gomar, M. \& Mandil, J. (2011). Terapia cognitiva con niño y adolescentes: aportes técnicos ( $3^{a}$ ed.). Buenos Aires: Librería Akadia Editorial.

Caballo, V. (1997). Manual para el tratamiento cognitivo-conductual de los trastornos psicológicos Vol. 1. trastornos por ansiedad, sexuales, afectivos y psicóticos. Madrid: Siglo XXI de España Editores.

Caballo, V., \& Simón, M. A. (2002). Manual de psicología clínica infantil $y$ del adolescente. Madrid: Ediciones Pirámide.

Dattilio, F. M., \& Padesky, C. A. (1995). Terapia cognitiva con pareja. España: Desclée De Brouwer.

Ellis, A., \& Dryden, W. (1989). Práctica de la terapia racional emotiva. Bilbao: Desclée De Brouwer.

Friedberg, R. D., \& McClure J. M. (2005). Práctica clínica de la terapia cognitiva con niños. Barcelona España: Paidós.

Froján, M. X., \& Becoña, E. (1999). El habito de fumar y su tratamiento: revisión de los avances en los últimos diez años de investigación. Revista de psicología general y aplicada. 52(4), 463-476.

Froján-Praga, M. J., \& Calero-Elvira, A. (2011). Guía para el uso de la reestructuración cognitiva como un procedimiento de moldeamiento. Behavioral Psychology / Psicología conductual. 19 (3),659-682

Galasso, L. (2011). La nueva psicología breve y eficaz: Terapia cognitivo conductual ( $2^{a}$ ed.). Buenos Aires: Psicología Argentina.

Hernández, J. (2017). Trastornos psicológicos: un punto de unión entre la TCC y la Neuropsicología. PSYCIENCIA. Recovered from: https://www.psyciencia.com/neuropsicobiologia-terapia-congnitivoconductual/ el 05 de noviembre del 2019.

Hernández, N. A., \& Sánchez, J. C. (2007). Manual de psicoterapia cognitivo-conductual para trastornos de la salud. México: Libros en red

Holland, J. G. \& Skinner, B. F. (1990). Análisis de la Conducta: Texto programado (2a $2^{a}$. .). México: Trillas.

Lega, L., Caballo, V., \& Ellis, A. (1997). Teoría y práctica de la terapia racional emotivo-conductual. Madrid: Siglo XXI de España editores.

Mahoney, M. J. (1974). Cognition and behavior modification. Cambridge: Ballinger Publishing.

Meichenbaum, D. (1974). Self-Instructional Strategy Trainning: a cognitive prothesis for the aged. Human develop. 17(4), 273-280.

Morales-Domínguez, Z. (2012). Intervención cognitivo-conductual en un caso de tricotilomanía. Acción Psicológica, 9(2), 131-142 , doi: 10.5944/ap.9.2.4111

Nezu, A. M., Nezu, C. M., \& Lombardo E. (2006). Formulación de casos y diseños de tratamientos cognitivo-conductuales: un enfoque basado en problemas. México: Manual Moderno

Pérez-Álvarez, M. (2019). Psicoterapia como ciencia humana, más que tecnológica. Papeles del Psicólogo. 40(1), pp. 1-14

Pérez, M., \& Fernández J. R. (2008). Más allá de la salud mental: la psicología en atención primaria. Papeles del Psicólogo. 29(3), 251270

Pérez, V., Gutiérrez, M. T., García, A. \& Gómez, J (2010). Procesos psicológicos básicos, un análisis funcional. España: Librería UNED

Ruiz, F. A. Díaz G. M. \& Villalobos C. A. (2013). Manual de técnicas de intervención cognitivo conductuales. Bilbao: Desclée De Brouwer.
Stallard, P. (2007). Pensar bien - sentirse bien. España: Desclée de brouwer

Wolpe, J., (1958). Psychotherapy by Reciprocal Inhibition, Stanford University Press, Stanford. 